\title{
INFLUENCE OF HARVEST TIMES ON YELLOW PASSION FRUIT PHYSICOCHEMICAL CHARACTERISTICS
}

\author{
INFLUENNCIA DE ÉPOCAS DE COLHEITA EM CARACTERÍSTICAS FÍSICO- \\ QUÍMICAS DO MARACUJAZEIRO AZEDO
}

\author{
Ana Montserrat Treitler DANTAS ${ }^{1}$; Anne Pinheiro COSTA ${ }^{1}$; José Ricardo PEIXOTO ${ }^{1}$; Fábio \\ Gelape FALEIRO ${ }^{2}$;ichelle Souza VILELA ${ }^{1}$; Márcio de Carvalho PIRES ${ }^{1}$ \\ 1. Faculdade de Agronomia e Medicina Veterinária, Universidade de Brasília, Campus Darcy Ribeiro, Asa Norte, 70910-900, Brasília, \\ DF, Brasil. annecosta@gmail.com; 2. Empresa Brasileira de Pesquisa Agropecuária, Embrapa, Planaltina, DF, Brasil.
}

\begin{abstract}
Yellow passion fruit (Passiflora edulis Sims) is mainly commercialized for in natura consumption. However, fruits are equally important for industrial purposes in the production of whole juice, concentrated juice, and frozen pulp. Therefore, the objective of this study was to evaluate fruit physicochemical characteristics of yellow passion fruit genotypes cultivated in the Federal District, Brazil and harvested at three distinct harvest times. The experiment consisted of a complete randomized block design with four replications, 14 genotypes, three harvest times (February, March, and April), and eight plants per plot. Fruits harvested in February presented greater pulp weight and total soluble solids to titratable acidity ratio (TSS/TA). The highest pulp yield was observed in March, and the greatest fruit longitudinal length was obtained in April. Fruit weight and equatorial diameter, peel thickness and weight, number of seeds per fruit, pulp pH, and ash content presented greater values for fruits harvested in April. In contrast, greater contents of TSS and reducing sugar were observed in pulps from fruits harvested in February. Genotype AP-01 stood out for its greatest fruit weight, fruit equatorial diameter, and number of seeds per fruit. AR-02, FP-01, and Vermelho Ingaí presented the greatest pulp yield, pulp weight, and TSS content, respectively. The genotypes evaluated in this study are suitable for industrial purposes due to the oval-shaped fruits with low pH (2.38 to 2.90) and high TA (3.50 to 5.60\%) values. Peel thickness values were high, indicating adequate conditions for long distance transportation.
\end{abstract}

KEYWORDS: Passiflora edulis Sims. Genetic breeding. Fruit quality.

\section{INTRODUCTION}

Currently, fruiticulture has been considered as a paramount agricultural activity for the Brazilian agriculture due to its high demand for labor in the field. Of the 150 passion fruit species native to Brazil, more than 60 of them produce fruits that can be directly or indirectly used as food (KISHORE et al., 2011). Yellow passion fruit (Passiflora edulis Sims) has stood out for its marked expansion, especially in the domestic market, at different consumer segments. Brazil is one of the world's largest producers of passion fruit $(703,489$ tons), with potential production and market demand that confirm the relevance of this crop for the Brazilian economy (IBGE, 2016).

Yellow passion fruit is commercialized mainly in the forms of juice and in natura. According to Junqueira et al. (2010), fruit quality for in natura consumption or for industry purposes is guaranteed by the analysis of the physicochemical characteristics of fruits, with evaluations on the flavor and organoleptic attributes. Some characteristics, such as pulp weight, fruit weight, fruit longitudinal length and equatorial diameter have been identified as relevant variables in passion fruit breeding programs aimed at obtaining genotypes with commercial quality for the in natura market (FERREIRA et al., 2010). Conversely, juice yield, acidity, constant color, total soluble solids (BRUCKNER et al., 2002), percentage of pulp, peel thickness, and peel weight are important attributes for the industry (FERREIRA et al., 2010).

Changes in the peel color and chemical composition of the fruits are observed during maturation (SALOMÃO, 2002), such as sugar accumulation and acidity reduction (CHITARRA; CHITARRA, 2005). Therefore, the objective of this study was to evaluate fruit physicochemical characteristics of 14 genotypes of yellow passion fruit harvested at three different harvest times. Based on these evaluations, the study aimed to identify genotypes with desirable physicochemical characteristics and with high pulp yield, total soluble solids (TSS) content, number of seeds per fruit, and thin peel thickness.

\section{MATERIAL AND METHODS}

The experiment was conducted at Água Limpa Farm $\left(16^{\circ} \mathrm{S}, 48^{\circ} \mathrm{W}, 1,100 \mathrm{~m}\right.$ asl), belonging to University of Brasilia (UnB), located in Brasilia, DF, Brazil. The climate of the region is considered as AW, according to the Köppen classification, with 
rainy summer (October-April) and dry winter (MaySeptember). The genotypes evaluated in this study were obtained from Embrapa and UnB and were selected based on yield, fruit quality, and resistance to diseases. Plants were arranged in the field, spaced at $3 \mathrm{~m}$ between rows and $3 \mathrm{~m}$ between plants, totaling 1,111 plants/ha. The crop was managed using a trellis fence system, with $6 \mathrm{~m}$-distant wooden stakes and two pieces of smooth wire, at 2 and $1.50 \mathrm{~m}$ from the ground, and all cultural practices typically recommended for passion fruit cultivation. No artificial pollination was performed to increase fruiting.

The experiment consisted of a complete randomized block design with four replications, 14 genotypes, three harvest times (February, March, and April), and eight plants per plot. Samples of 10 fruits per genotype were collected from each of the four replications, at each of the three harvest times, harvested from the ground, totaling 1680 fruits at full physiological maturation stage. The following physicochemical analyses were performed: fruit weight $(\mathrm{g})$, fruit longitudinal length $(\mathrm{mm})$, fruit equatorial diameter $(\mathrm{mm})$, fruit length to diameter ratio $(\mathrm{L} / \mathrm{D})$, peel thickness $(\mathrm{mm})$, peel weight $(\mathrm{g})$, pulp weight with seeds (g), pulp yield (\%), number of seeds per fruit, pulp total soluble solids (TSS; ${ }^{\circ}$ Brix), pulp titratable acidity (TA; \% citric acid), pulp pH, pulp TSS/TA ratio, pulp protein (\%), pulp reducing sugar (\%), pulp moisture (\%), and pulp ash content $(\%)$.
Fruits were measured using a digital caliper and weighed on an analytical scale. Pulp yield was obtained by the pulp to fruit weight ratio. Fruit transverse direction was used as a standard to measure the peel thickness. Seeds were separated from the pulp, washed, dried in a forced-aircirculation oven, and weighed. The number of seeds per fruit was determined by the ratio between the number of seeds present in two grams and the total weight of the seeds. All physicochemical analyses were performed according to the Analytical Rules of Adolfo Lutz Institute (IAL, 2008).

Data were subject to analysis of variance, and means were compared by the Duncan's test, at $5 \%$ probability. Regression analyses were performed to evaluate linear and quadratic responses of genotypes to harvest times. Statistical analyses were performed using the SISVAR statistical program.

\section{RESULTS AND DISCUSSION}

Fruits harvested in February presented greater pulp weight and TSS/TA. The highest pulp yield was observed in March, and the greatest fruit longitudinal length was obtained in April (Table 1). Fruits harvested in February did not differ significantly from those harvested in March and April for L/D ratio and pulp moisture. No genotype $\mathrm{x}$ harvest time interaction was observed for any of these characteristics.

Table 1. Fruit longitudinal length (FL; mm), fruit length to diameter ratio (L/D), pulp weight (PW; g), pulp yield (PY; \%), pulp total soluble solids to titratable acidity ratio (TSS/AT), and pulp moisture (PM; $\%$ ) in yellow passion fruit (Passiflora edulis Sims), harvested at three different harvest times. Brasilia, DF, Brazil.

\begin{tabular}{ccccccc}
\hline Harvest time & FL $^{\mathbf{1}}$ & L/D & PW & PY & TSS/AT & PM \\
\hline February & $77.39 \mathrm{c}$ & $1.19 \mathrm{a}$ & $70.96 \mathrm{a}$ & $33.34 \mathrm{~b}$ & $3.02 \mathrm{a}$ & $79.92 \mathrm{a}$ \\
March & $80.86 \mathrm{~b}$ & $1.11 \mathrm{a}$ & $39.78 \mathrm{~b}$ & $39.41 \mathrm{a}$ & $2.83 \mathrm{ab}$ & $89.33 \mathrm{a}$ \\
April & $92.27 \mathrm{a}$ & $1.19 \mathrm{a}$ & $29.20 \mathrm{c}$ & $37.04 \mathrm{ab}$ & $2.75 \mathrm{~b}$ & $79.92 \mathrm{a}$ \\
\hline CV $(\%)$ & 1.684 & 15.394 & 12.501 & 7.566 & 4.837 & 9.563 \\
\hline
\end{tabular}

${ }^{1}$ Different lowercase letters in the columns indicate significant differences (Duncan's test, $\mathrm{P} \leq 0.05$ ).

Genotypes presented differences regarding fruit longitudinal length, L/D ratio, pulp weight, and pulp yield (Table 2). Fruit longitudinal length ranged from 72.10 (Vermelho Ingaí) to $88.76 \mathrm{~cm}$ (RC-3), and the highest L/D ratio was verified in MAR20\#23 (1.88), which significantly differed from all the other genotypes. According to Medeiros et al. (2009), fruits with L/D ratio close to 1.00 are round-shaped. Oval-shaped fruits (oblong) were observed in this study, which is the result of a ratio greater than 1.00. Oblong fruits are preferred by the industry for presenting juice yield of up to $10 \%$ higher than round-shaped fruits (FORTALEZA et al., 2005).

Genotypes FP-01 and MAR20\#23 showed the greatest $(60.84 \mathrm{~g})$ and the lowest $(39.75 \mathrm{~g})$ pulp weight, respectively. Mean pulp weight for all genotypes was $45.46 \mathrm{~g}$ (Table 2). Similarly, Negreiros et al. (2008) reported a variation from 29.15 to $70.05 \mathrm{~g}$ for the pulp weight of half-sib progenies of yellow passion fruit, with a mean of $44.46 \mathrm{~g}$. The highest pulp yield was observed for 
AR-02 (37.58\%), while MAR20\#03 presented the lowest pulp yield $(26.67 \%)$. According to Farias et al. (2007), the yield value considered as adequate for the industry should be close to $45 \%$. In general, low pulp yield directly correlates with greater peel thickness (FERREIRA et al., 2010; GRECO et al., 2014), which could explain the suboptimal yield

TSS/TA determines the sweet or acidic nature of the pulp, and usually, the higher the value of this ratio, the more pleasant is the juice or pulp taste (MACHADO et al., 2003). This ratio is useful to determine the maturation stages since it tends to increase with fruit ripening, due to the inverse behavior of TSS and TA. The ratio can vary depending on the cultivar, location, and harvest time (GOMES et al., 2006). However, no statistical difference among the genotypes was reported for this variable (Table 2), corroborating the results presented by Greco et al. (2014). In the present study, the TSS/TA varied between 2.64 (FP-01) and 3.12 (RC-3), with a mean value of 2.87 .

No statistical difference was observed for the variable pulp moisture among the studied genotypes, ranging between 80.83 and $89.63 \%$ (Table 2). The mean pulp moisture content was $85.92 \%$, lower than that reported for the frozen pulp
(88.90\%) and higher than that observed for in natura passion fruit (82.90\%) (TACO, 2011).

Genotype $\mathrm{x}$ harvest time interaction was detected for fruit weight, fruit equatorial diameter, peel thickness, peel weight, number of seeds per fruit, TSS, TA, pulp $\mathrm{pH}$, pulp protein, pulp reducing sugar, and pulp ash content. Among these variables, an increasing linear response was observed for fruit weight, fruit equatorial diameter, peel thickness, peel weight, number of seeds per fruit, pulp $\mathrm{pH}$, and pulp ash content. These characteristics presented an increase in relation to harvest times. Therefore, fruits harvested in April showed higher values for these characteristics than those harvested in February and March.

For fruit weight, values ranged from $67.67 \mathrm{~g}$ (MAR20\#23) to $259.75 \mathrm{~g}$ (AP-01) (Table 3). Fruits harvested in April presented a mean weight of 192.5 g. This value is higher than the national mean (120 g) (FARIAS et al., 2007), higher than the mean obtained by Campos et al. (2013) (166.7 g), and higher than that recorded for passion fruits cultivated under an alternative production system (191g) (CAMPOS et al., 2007). Abreu et al. (2009) also recorded greater fruit weight, in April, for passion fruit genotypes cultivated in Brasilia, DF.

Table 2. Fruit longitudinal length (FL; mm), fruit length to diameter ratio (L/D), pulp weight (PW; g), pulp yield (PY; \%), pulp total soluble solids to titratable acidity ratio (TSS/AT), and pulp moisture (PM; $\%$ ) in 14 yellow passion fruit (Passiflora edulis Sims) genotypes, harvested at three different harvest times. Brasilia, DF, Brazil.

\begin{tabular}{ccccccc}
\hline Genotypes & FL & L/D & PW & PY & TSS/AT & PM \\
\hline MAR20\#03 & $85.14 \mathrm{abc}$ & $1.11 \mathrm{~b}$ & $40.13 \mathrm{~b}$ & $26.67 \mathrm{~b}$ & $2.77 \mathrm{a}$ & $82.55 \mathrm{a}$ \\
GA-AR1*AG & $86.73 \mathrm{ab}$ & $1.13 \mathrm{~b}$ & $49.00 \mathrm{ab}$ & $33.25 \mathrm{ab}$ & $3.02 \mathrm{a}$ & $80.95 \mathrm{a}$ \\
MAR20\#36 & $80.93 \mathrm{~cd}$ & $1.12 \mathrm{~b}$ & $49.96 \mathrm{ab}$ & $37.25 \mathrm{a}$ & $3.01 \mathrm{a}$ & $84.41 \mathrm{a}$ \\
AR-02 & $83.84 \mathrm{abc}$ & $1.08 \mathrm{~b}$ & $47.88 \mathrm{ab}$ & $37.58 \mathrm{a}$ & $2.80 \mathrm{a}$ & $88.02 \mathrm{a}$ \\
AR-01 & $86.12 \mathrm{ab}$ & $1.11 \mathrm{~b}$ & $44.09 \mathrm{ab}$ & $31.75 \mathrm{ab}$ & $2.76 \mathrm{a}$ & $89.25 \mathrm{a}$ \\
MAR20\#09 & $84.54 \mathrm{abc}$ & $1.13 \mathrm{~b}$ & $44.38 \mathrm{ab}$ & $35.17 \mathrm{ab}$ & $2.72 \mathrm{a}$ & $89.63 \mathrm{a}$ \\
YM FB200 & $81.64 \mathrm{bcd}$ & $1.09 \mathrm{~b}$ & $40.12 \mathrm{~b}$ & $37.25 \mathrm{a}$ & $2.87 \mathrm{a}$ & $82.51 \mathrm{a}$ \\
AP-01 & $87.84 \mathrm{a}$ & $1.09 \mathrm{~b}$ & $48.38 \mathrm{ab}$ & $28.17 \mathrm{~b}$ & $2.77 \mathrm{a}$ & $89.12 \mathrm{a}$ \\
RC-3 & $88.76 \mathrm{a}$ & $1.16 \mathrm{~b}$ & $44.38 \mathrm{ab}$ & $30.92 \mathrm{ab}$ & $3.12 \mathrm{a}$ & $87.95 \mathrm{a}$ \\
VERMELHO INGAÍ & $72.10 \mathrm{e}$ & $1.09 \mathrm{~b}$ & $40.12 \mathrm{~b}$ & $35.00 \mathrm{ab}$ & $2.91 \mathrm{a}$ & $88.75 \mathrm{a}$ \\
EC-RAM & $88.14 \mathrm{a}$ & $1.14 \mathrm{~b}$ & $41.52 \mathrm{~b}$ & $27.67 \mathrm{~b}$ & $2.86 \mathrm{a}$ & $88.01 \mathrm{a}$ \\
MAR20\#46 & $77.03 \mathrm{de}$ & $1.08 \mathrm{~b}$ & $45.99 \mathrm{ab}$ & $34.58 \mathrm{ab}$ & $2.87 \mathrm{a}$ & $88.45 \mathrm{a}$ \\
FP-01 & $84.77 \mathrm{abc}$ & $1.10 \mathrm{~b}$ & $60.84 \mathrm{a}$ & $27.67 \mathrm{~b}$ & $2.64 \mathrm{a}$ & $82.47 \mathrm{a}$ \\
MAR20\#23 & $78.41 \mathrm{de}$ & $1.88 \mathrm{a}$ & $39.75 \mathrm{~b}$ & $33.33 \mathrm{~b}$ & $3.05 \mathrm{a}$ & $80.83 \mathrm{a}$ \\
\hline CV $(\%)$ & 6.659 & 57.830 & 39.891 & 27.581 & 1.93 & 11.982 \\
\hline
\end{tabular}

Different lowercase letters in the columns indicate significant differences (Duncan's test, $\mathrm{P} \leq 0.05$ ). 
Table 3. Fruit weight (FW; g), number of seeds per fruit (NSF), peel thickness (PT; mm), pulp pH, pulp total soluble solids (TSS; ${ }^{\circ}$ Brix), and pulp titratable acidity (TA; \% citric acid) in 14 yellow passion fruit (Passiflora edulis Sims) genotypes, harvested at three different harvest times. Brasilia, DF, Brazil.

\begin{tabular}{|c|c|c|c|c|c|c|c|c|}
\hline & \multirow[b]{2}{*}{$\begin{array}{l}\text { Harvest } \\
\text { time }\end{array}$} & \multicolumn{7}{|c|}{ Genotypes } \\
\hline & & MAR20\#03 & GA-AR1*AG & MAR20\#36 & AR-02 & AR-01 & MAR20\#09 & YM FB200 \\
\hline \multirow{3}{*}{ FW } & 1 & $98.37 \mathrm{cAB}^{(1)}$ & $102.42 \mathrm{cAB}$ & $88.04 \mathrm{bAB}$ & $96.06 \mathrm{bAB}$ & $80.47 \mathrm{cAB}$ & $88.65 \mathrm{bAB}$ & $89.26 \mathrm{cAB}$ \\
\hline & 2 & $135.37 \mathrm{bAB}$ & $144.98 \mathrm{bAB}$ & $123.30 \mathrm{bB}$ & $121.83 \mathrm{aAB}$ & $134.65 \mathrm{bAB}$ & $119.64 \mathrm{bB}$ & $140.24 \mathrm{bAB}$ \\
\hline & 3 & $226.98 \mathrm{aAB}$ & 189.68 aBCD & $193.54 \mathrm{aBCD}$ & $159.26 \mathrm{aBCD}$ & $192.17 \mathrm{aBCD}$ & $200.00 \mathrm{aBCD}$ & 199.30 a BCD \\
\hline \multirow{3}{*}{ NSF } & 1 & $100.75 \mathrm{bA}$ & $91.00 \mathrm{bA}$ & $84.00 \mathrm{bA}$ & $74.25 \mathrm{aA}$ & $74.25 \mathrm{bA}$ & $124.25 \mathrm{bA}$ & $70.50 \mathrm{cA}$ \\
\hline & 2 & $118.75 \mathrm{bA}$ & $108.50 \mathrm{bA}$ & $98.25 \mathrm{bA}$ & $123.75 \mathrm{aA}$ & $102.75 \mathrm{bA}$ & $157.75 \mathrm{bA}$ & $141.75 \mathrm{bA}$ \\
\hline & 3 & $251.00 \mathrm{aCD}$ & $235.00 \mathrm{aD}$ & $503.75 \mathrm{aA}$ & $124.00 \mathrm{aE}$ & $292.00 \mathrm{aBCD}$ & $268.00 \mathrm{aCD}$ & $238.75 \mathrm{aD}$ \\
\hline \multirow{3}{*}{ PT } & 1 & $6.43 \mathrm{cBC}$ & $7.50 \mathrm{aAB}$ & $6.70 \mathrm{bABC}$ & $7.91 \mathrm{aA}$ & $6.93 \mathrm{aABC}$ & $8.50 \mathrm{aAB}$ & $6.66 \mathrm{bABC}$ \\
\hline & 2 & $7.61 \mathrm{bA}$ & $7.68 \mathrm{aA}$ & $7.59 \mathrm{bA}$ & $7.63 \mathrm{aA}$ & $7.44 \mathrm{aA}$ & $7.40 \mathrm{aA}$ & $7.21 \mathrm{bA}$ \\
\hline & 3 & $9.82 \mathrm{aA}$ & $8.74 \mathrm{aABCD}$ & $9.21 \mathrm{aABC}$ & $7.56 \mathrm{aDE}$ & $7.80 \mathrm{aCDE}$ & $7.38 \mathrm{aABCD}$ & 8.88 aABCD \\
\hline \multirow{3}{*}{ pH } & 1 & $2.67 \mathrm{bAB}$ & $2.50 \mathrm{bABC}$ & $2.48 \mathrm{bABC}$ & $2.47 \mathrm{aABC}$ & $2.38 \mathrm{bC}$ & $2.50 \mathrm{aABC}$ & $2.50 \mathrm{aABC}$ \\
\hline & 2 & $2.47 \mathrm{bABC}$ & $2.45 \mathrm{bBC}$ & $2.48 \mathrm{bABC}$ & $2.50 \mathrm{aABC}$ & $2.45 \mathrm{abBC}$ & $2.60 \mathrm{aA}$ & $2.60 \mathrm{aA}$ \\
\hline & 3 & $2.77 \mathrm{aBC}$ & $2.63 \mathrm{aDE}$ & $2.90 \mathrm{aA}$ & $2.57 \mathrm{aDEF}$ & $2.55 \mathrm{aDEF}$ & $2.50 \mathrm{aEF}$ & $2.55 \mathrm{aDEF}$ \\
\hline \multirow{3}{*}{ TSS } & 1 & $13.50 \mathrm{aAB}$ & $13.00 \mathrm{aAB}$ & $13.50 \mathrm{aAB}$ & $13.25 \mathrm{aAB}$ & $13.00 \mathrm{aAB}$ & $13.00 \mathrm{aAB}$ & $12.75 \mathrm{aAB}$ \\
\hline & 2 & $12.25 \mathrm{aAB}$ & $12.50 \mathrm{aAB}$ & $12.75 \mathrm{aAB}$ & $11.75 \mathrm{bA}$ & $12.25 \mathrm{abAB}$ & $11.75 \mathrm{aAB}$ & $12.00 \mathrm{aAB}$ \\
\hline & 3 & $12.00 \mathrm{aAB}$ & $11.00 \mathrm{bBCD}$ & $11.00 \mathrm{bAB}$ & $11.25 \mathrm{bBCD}$ & $11.00 \mathrm{bBCD}$ & $10.00 \mathrm{bCD}$ & $11.75 \mathrm{aABC}$ \\
\hline \multirow{3}{*}{ TA } & 1 & $4.80 \mathrm{aAB}$ & $4.40 \mathrm{aAB}$ & $5.00 \mathrm{aA}$ & $4.60 \mathrm{aAB}$ & $5.20 \mathrm{aA}$ & $4.20 \mathrm{aAB}$ & $4.00 \mathrm{aB}$ \\
\hline & 2 & $4.70 \mathrm{aABC}$ & $4.30 \mathrm{aBC}$ & $4.20 \mathrm{bBC}$ & $4.40 \mathrm{aBC}$ & $4.50 \mathrm{abBC}$ & $4.30 \mathrm{aBC}$ & $4.30 \mathrm{aBC}$ \\
\hline & 3 & $4.40 \mathrm{aAB}$ & $4.40 \mathrm{aAB}$ & $3.50 \mathrm{bB}$ & $4.10 \mathrm{aAB}$ & $3.70 \mathrm{bAB}$ & $4.40 \mathrm{aAB}$ & $4.70 \mathrm{aA}$ \\
\hline
\end{tabular}

Table 3. Continuation.

\begin{tabular}{ccccccccc}
\hline & \multirow{7}{*}{$\begin{array}{c}\text { Harvest } \\
\text { time }\end{array}$} & AP-01 & RC-3 & Vermelho Ingaí & EC-RAM & MAR20\#46 & FP-01 & MAR20\#23 \\
\hline FW & 1 & $74.60 \mathrm{cAB}$ & $116.85 \mathrm{bA}$ & $67.97 \mathrm{cB}$ & $87.75 \mathrm{cAB}$ & $90.67 \mathrm{bAB}$ & $84.22 \mathrm{bAB}$ & $67.67 \mathrm{cB}$ \\
\hline
\end{tabular}




\begin{tabular}{|c|c|c|c|c|c|c|c|c|}
\hline & 2 & $149.37 \mathrm{bAB}$ & $124.60 \mathrm{bB}$ & $112.74 \mathrm{bB}$ & $128.00 \mathrm{bAB}$ & $121.28 \mathrm{bB}$ & $171.21 \mathrm{aA}$ & $116.25 \mathrm{bB}$ \\
\hline & 3 & $259.75 \mathrm{aA}$ & $182.50 \mathrm{aBCD}$ & $157.82 \mathrm{aD}$ & $212.57 \mathrm{aBC}$ & $172.05 \mathrm{aCD}$ & $188.54 \mathrm{aBCD}$ & $161.25 \mathrm{aD}$ \\
\hline \multirow{3}{*}{ NSF } & 1 & $60.25 \mathrm{bA}$ & $85.00 \mathrm{bA}$ & $68.75 \mathrm{bA}$ & $58.50 \mathrm{bA}$ & $78.25 \mathrm{bA}$ & $111.75 \mathrm{bA}$ & $61.00 \mathrm{bA}$ \\
\hline & 2 & $80.00 \mathrm{bA}$ & $91.75 \mathrm{bA}$ & $129.50 \mathrm{bA}$ & $84.00 \mathrm{bA}$ & $115.75 \mathrm{bA}$ & $110.50 \mathrm{bA}$ & $100.50 \mathrm{bA}$ \\
\hline & 3 & $508.75 \mathrm{aA}$ & $324.00 \mathrm{bBC}$ & $268.25 \mathrm{aCD}$ & $230.75 \mathrm{aD}$ & $364.25 \mathrm{aB}$ & $306.50 \mathrm{aBCD}$ & $293.75 \mathrm{aBCD}$ \\
\hline \multirow{3}{*}{ PT } & 1 & $6.23 \mathrm{bBC}$ & $7.97 \mathrm{aA}$ & $6.74 \mathrm{bABC}$ & $7.18 \mathrm{bAB}$ & $5.59 \mathrm{cC}$ & $6.94 \mathrm{bABC}$ & $6.44 \mathrm{bBC}$ \\
\hline & 2 & $7.90 \mathrm{aA}$ & $7.04 \mathrm{aA}$ & $7.39 \mathrm{abA}$ & $7.76 \mathrm{abA}$ & $7.80 \mathrm{bA}$ & $7.69 \mathrm{bA}$ & $7.42 \mathrm{abA}$ \\
\hline & 3 & $8.40 \mathrm{aBCDE}$ & $7.02 \mathrm{aE}$ & $8.50 \mathrm{aABCDE}$ & $8.91 \mathrm{aABCD}$ & $8.98 \mathrm{aABC}$ & $9.25 \mathrm{aAB}$ & $8.13 \mathrm{aBCDE}$ \\
\hline \multirow{3}{*}{ pH } & 1 & $2.50 \mathrm{aABC}$ & $2.45 \mathrm{bABC}$ & $2.50 \mathrm{aABC}$ & $2.55 \mathrm{aAB}$ & $2.50 \mathrm{bABC}$ & $2.43 \mathrm{bBC}$ & $2.58 \mathrm{bA}$ \\
\hline & 2 & $2.43 \mathrm{bBC}$ & $2.43 \mathrm{bBC}$ & $2.48 \mathrm{aABC}$ & $2.43 \mathrm{aBC}$ & $2.55 \mathrm{bAB}$ & $2.38 \mathrm{bC}$ & $2.48 \mathrm{bABC}$ \\
\hline & 3 & $2.60 \mathrm{aDEF}$ & $2.60 \mathrm{aDEF}$ & $2.48 \mathrm{aF}$ & $2.55 \mathrm{aDEF}$ & $2.77 \mathrm{aBC}$ & $2.68 \mathrm{aCD}$ & $2.85 \mathrm{aAB}$ \\
\hline \multirow{3}{*}{ TSS } & 1 & $12.25 \mathrm{aB}$ & $13.25 \mathrm{aAB}$ & $14.25 \mathrm{aA}$ & $13.00 \mathrm{aAB}$ & $13.75 \mathrm{aAB}$ & $13.50 \mathrm{aAB}$ & $13.75 \mathrm{aAB}$ \\
\hline & 2 & $12.25 \mathrm{aAB}$ & $13.00 \mathrm{aAB}$ & $13.50 \mathrm{abAB}$ & $12.75 \mathrm{aAB}$ & $11.00 \mathrm{bB}$ & $12.00 \mathrm{bAB}$ & $13.00 \mathrm{aA}$ \\
\hline & 3 & $11.00 \mathrm{aAB}$ & $12.50 \mathrm{aA}$ & $12.25 \mathrm{bAB}$ & $10.00 \mathrm{bCD}$ & $12.25 \mathrm{bAB}$ & $11.75 \mathrm{bABC}$ & $9.75 \mathrm{bD}$ \\
\hline \multirow{3}{*}{ TA } & 1 & $4.00 \mathrm{bB}$ & $4.40 \mathrm{aAB}$ & $4.60 \mathrm{aAB}$ & $4.60 \mathrm{aAB}$ & $4.20 \mathrm{aAB}$ & $4.70 \mathrm{bAB}$ & $4.00 \mathrm{aB}$ \\
\hline & 2 & $4.90 \mathrm{aABC}$ & $4.10 \mathrm{aBC}$ & $5.00 \mathrm{aAB}$ & $4.00 \mathrm{aC}$ & $4.80 \mathrm{aABC}$ & $5.60 \mathrm{aA}$ & $4.20 \mathrm{aBC}$ \\
\hline & 3 & $4.20 \mathrm{abAB}$ & $4.10 \mathrm{aAB}$ & $4.20 \mathrm{aAB}$ & $4.00 \mathrm{aAB}$ & $4.30 \mathrm{aAB}$ & $4.20 \mathrm{bAB}$ & $3.80 \mathrm{aAB}$ \\
\hline
\end{tabular}

Different lowercase letters in the columns indicate significant differences (Duncan's test, $\mathrm{P} \leq 0.05$ ). 
The fruit equatorial diameter ranged from 49.50 (MAR20\#23) to $81.33 \mathrm{~mm}(\mathrm{GA}-\mathrm{AR} 1 * \mathrm{AG})$ in February, from 68.95 (Vermelho Ingaí) to $76.95 \mathrm{~mm}$ (RC-3) in March, and from 71.38 (MAR20\#23) to $90.25 \mathrm{~mm}$ (AP-01) in April. Fruits harvested in April showed a mean equatorial diameter of 77.06 $\mathrm{mm}$, which is superior to the value reported by Abreu et al. (2009) for fruits harvested in the same month. Fruit longitudinal length and equatorial diameter, together with the peel color, are useful physical indices for the classification of fruits intended for fresh fruit market (CAMPOS et al., 2013). These variables determine the product acceptance and influence the price. In general, larger, attractive-looking fruits are preferred by consumers.

Peel thickness values varied from 5.59 (MAR20\#46) to $9.82 \mathrm{~cm}$ (MAR20\#03). An increase in the mean peel thickness was observed between the first $(6.98 \mathrm{~cm})$ and the third harvest time $(8.47$ $\mathrm{cm})$, indicating a need for selection in order to reduce these values (Table 3). Peel thickness is determinant for the industry and the fresh fruit market. Several studies have indicated a negative correlation between peel thickness and pulp and juice yield in yellow passion fruit (CAVICHIOLI et al., 2008; ABREU et al., 2009; FERREIRA et al., 2010; GRECO et al., 2014). Such correlation could explain the lowest mean pulp yield (26.67\%) observed for genotype MAR20\#03 in this study. Although peel thickness may result in lower pulp and juice yields, fruits with thicker peel have greater resistance to transport over long distances, due to less post-harvest losses caused by physical injury (SILVA et al., 2015).

The peel weight represented from 22.5 (MAR20\#46) to $80.2 \%$ (AP-01) of the fruit at the first harvest time. The variation decreased throughout the harvest time, ranging between 48.5 (FP-01) and 75\% (EC-RAM) in March, and between 55.4 (MAR20\#46) and 65.1\% (MAR20\#03) in April. Mean peel weight varied from 61.6 (April) to $67.3 \%$ (March) of the total fruit weight at the different harvest times.

The number of seeds per fruit ranged between 58.50 (EC-RAM) and 508.75 (AP-01) (Table 3). A significant difference was observed among the genotypes for this characteristic only at the third harvest time. The genotypes presented a mean of 81.6, 117.7, and 300.6 seeds per fruit in February, March, and April, respectively. A greater number of seeds per fruit was also observed in April by Abreu et al. (2009). Possibly, the number of pollinating agents of the genus Xylocopa spp. decreased, or the usual rainfall of February and
March restricted the visitation of these agents, reducing pollination, fruiting, and number of seeds per fruit.

Pulp pH values ranged from 2.38 (AR-01 and FP-01) to 2.90 (MAR20\#36) (Table 3), with higher mean values observed in April (2.64), as reported by Abreu et al. (2009). These results suggest the use of these genotypes for industrial purposes since the observed values are adequate for storage (FOLEGATTI; MATSUURA, 2002). Fruits with $\mathrm{pH}$ values between 2.3 and 3.3 are desirable for the production of whole passion fruit juice (FOLEGATTI; MATSUURA, 2002), while fruits with $\mathrm{pH}$ values between 2.5 and 3.5 are more suitable for the production of juice concentrate than for natural juice consumption (TOCCHINI et al., 1994).

Pulp ash content varied from 0.13 (MAR20\#09 and MAR20\#03) to $1.31 \%$ (MAR20\#46). The mean ash content recorded for the pulp of the evaluated genotypes was $0.15 \%$ in February, $0.40 \%$ in March, and $0.92 \%$ in April. Only fruits of the third harvest time presented values within the expected range for frozen pulp and in natura passion fruit, i.e., 0.5 and $0.8 \%$, (TACO, 2011).

TSS and reducing sugar contents presented a decreasing linear response. In general, pulps from fruits harvested in February showed higher contents of TSS and reducing sugar than those harvested in April. The genotypes presented values between 9.75 (MAR20\#23) and $14.25^{\circ}$ Brix (Vermelho Ingaí) for TSS contents (Table 3). TSS content is used to indicate fruit quality. Fruits with TSS contents higher than $13^{\circ}$ Brix are preferred for both fresh fruit market and industry (BRUCKNER et al., 2002). The genotypes presented mean TSS content of $13.30^{\circ}$ Brix (February), $12.30^{\circ}$ Brix (March), and $11.25^{\circ}$ Brix (April).

No statistical difference was reported for reducing sugar content of fruits harvested at the three harvest times for most of the evaluated genotypes. Overall, the highest values were observed for fruits harvested in February with a mean of $15.32 \%$. However, the highest reducing sugar content was recorded for MAR20\#46 (18.62\%), in April. Genotypes EC-RAM (9.55\%) and MAR20\#09 (9.80\%) presented the lowest sugar contents, both in April. According to Durigan and Durigan (2002), passion fruit must present about $38.10 \%$ of sugars; however, the 14 genotypes evaluated in this study presented mean values lower than that. This difference is possibly due to a genotypic effect and different soil and climatic conditions. 
Pulp protein content showed a quadratic response. Protein content in the fruits ranged between 0.47 (FP-01) and $1.55 \%$ (MAR20\#36), with mean values of $1.18 \%, 1.13 \%$, and $1.20 \%$ in the first, second, and third harvest times, respectively. According to TACO (2011), the expected protein contents in fresh fruits and frozen pulp are $2.0 \%$ and $0.8 \%$, respectively.

No significant regression was observed for the other characteristics evaluated. For TA, values ranged from 3.50 (MAR20\#36) to $5.60 \%$ (FP-01), with a mean acidity of $4.50 \%$ in February and March, and of $4.10 \%$ in April (Table 3). The evaluated genotypes presented values within limits between 3.0 and $5.0 \%$ reported for yellow passion fruit. In addition, they demonstrated favorable characteristics for the juice industry since fruits with acidity between 2.50 and $4.60 \%$ are ideal for the production of whole fruit juice (FOLEGATTI; MATSUURA, 2002). High TA is essential for the industry since it reduces the addition of acidifiers, providing nutritional improvement, food safety, and organoleptic quality (CAMPOS et al., 2013). Moreover, the high acidity of yellow passion fruit guarantees greater flexibility when adding sugar to the juice (SOUZA; SANDI, 2001).

\section{CONCLUSIONS}

TSS and $\mathrm{pH}$ values were compatible with undemanding passion fruit markets. Since no artificial pollination was performed, fruits presented pulp yield values lower than the standards demanded by the most important consuming centers. However, favorable characteristics for the juice industry were detected, such as oval-shaped fruits, low $\mathrm{pH}$, high TA values, and TSS contents equal to or greater than $13^{\circ}$ Brix for different genotypes and at distinct harvest times.

Peel thickness values were high, demonstrating adequate conditions for long distance transportation.

RESUMO: O maracujazeiro azedo (Passiflora edulis Sims) é comercializado principalmente para o consumo in natura. Entretanto, os frutos são igualmente importantes para fins industriais na produção de suco integral, suco concentrado e polpa congelada. Desta forma, o objetivo deste estudo foi avaliar as características físico-químicas dos frutos de genótipos de maracujazeiro azedo cultivados no Distrito Federal, Brasil, e colhidos em três épocas distintas. O experimento consistiu de um delineamento de blocos casualizados com quatro repetições, 14 genótipos, três épocas de colheita (Fevereiro, Março e Abril) e oito plantas por parcela. Frutos colhidos em Fevereiro apresentaram maior peso de polpa e relação entre sólidos solúveis totais e acidez titulável (SST/AT). O maior rendimento de polpa foi observado em Março e o maior comprimento longitudinal foi obtido em Abril. Peso e diâmetro equatorial do fruto, espessura e peso da casca, número de sementes por fruto, $\mathrm{pH}$ e conteúdo de cinzas da polpa apresentaram maiores valores para frutos colhidos em Abril. Ao contrário, maiores teores de SST e açúcar redutor foram observados em polpas de frutos colhidos em Fevereiro. O genótipo AP-01 se destacou por seus maiores peso de fruto, diâmetro equatorial do fruto e número de sementes por fruto. AR-02, FP-01 e Vermelho Ingaí apresentaram os maiores rendimento de polpa, peso de polpa e SST, respectivamente. Os genótipos avaliados neste estudo demonstraram adequação para fins industriais, exibindo frutos com formato ovalado com baixos valores de $\mathrm{pH}(2,38$ a 2,90) e elevada AT $(3,50$ a 5,60). A espessura da casca dos frutos foi elevada, refletindo condições adequadas para transporte a longas distâncias.

PALAVRAS-CHAVE: Passiflora edulis Sims. Melhoramento genético. Qualidade de frutos.

\section{REFERENCES}

ABREU, S. P. M.; PEIXOTO, J. R.; JUNQUEIRA, N. T. V.; SOUSA, M. A. F. Características físico-químicas de cinco genótipos de maracujazeiro-azedo cultivados no Distrito Federal. Revista Brasileira de Fruticultura, Jaboticabal, v. 31, n. 2, p. 487-491, 2009. https://doi.org/ 10.1590/S0100-29452009000300042

BRUCKNER, C. H.; MELETTI, L. M. M.; OTONI, W. C.; ZERBINI JÚNIOR, F. M. Maracujazeiro. In: BRUCKNER, C. H. (Ed.). Melhoramento de Fruteiras Tropicais. Viçosa: UFV, 2002. p. 373-410.

CAMPOS, V. B.; CAVALCANTE, L. F.; DANTAS, T. A. G.; MOTA, J. K. M.; RODRIGUES, A. C.; DINIZ, A. A. Caracterização física e química de frutos de maracujazeiro-amarelo sob adubação potássica, biofertilizante e cobertura morta. Revista Brasileira de Produtos Agroindustriais, Campina Grande, v. 9, $\mathrm{n}$. 1, p. 59-71, 2007. https://doi.org/10.15871/1517-8595/rbpa.v9n1p59-71 
CAMPOS, V. B.; FOGAÇA, T. S.; ALMEIDA, W. L.; BARBOSA, J. A.; OLIVEIRA, M. R. T.; GONDIM, S. C.; CAVALCANTE, L. F. Caracterização física e química de frutos de maracujá-amarelo comercializados em Macapá, Amapá. Revista Brasileira de Produtos Agroindustriais, Campina Grande, v. 15, n. 1, p. 27-33, 2013. https://doi.org/10.15871/1517-8595/rbpa.v15n1p27-33

CAVICHIOLI, J. C.; RUGGIERO, C.; VOLPE, C. A. Caracterização físico-química de frutos de maracujazeiro amarelo submetidos a iluminação artificial, irrigação e sombreamento. Revista Brasileira de Fruticultura, Jaboticabal, v. 30, n. 3, p. 649-656, 2008. https://doi.org/10.1590/S0100-29452008000300015

CHITARRA, M. L. F.; CHITARRA, A. B. Pós-colheita de frutos e hortaliças: fisiologia e manuseio, Lavras: UFLA, 2005. 785p.

DURIGAN, J. F.; DURIGAN, M. F. B. Característica dos frutos. In: MATSUURA, F.C.A.U.; FOLEGATTI, M.I.S. (Eds.). Maracujá - Pós-colheita. Brasília: Embrapa Informação Tecnológica, 2002. p. 13-15.

FARIAS, J. F.; SILVA, L. J. B.; ARAÚJO NETO, S. E.; MENDONÇA, V. Qualidade do maracujá-amarelo comercializado em Rio Branco, Acre. Revista Caatinga, Mossoró, v. 20, n. 3, p. 196-202, 2007.

FERREIRA, F. M.; NEVES, L. G.; BRUCKNER, C. H.; VIANA, A. P.; CRUZ, C. D.; BARELLI, M. A. A. Formação de super-caracteres para seleção de famílias de maracujazeiro amarelo. Acta Scientiarum, Maringá, v. 32, n. 2, p. 247-254, 2010. https://doi.org/10.4025/actasciagron.v32i2.3328

FOLEGATTI, M. I. S.; MATSUURA, F. C. A. U. Produtos. In: MATSUURA, F. C. A. U.; FOLEGATTI, M. I. S. (Eds.). Maracujá - Pós-colheita. Brasília: Embrapa Informação Tecnológica, 2002. p. 42-51.

FORTALEZA, J. M.; PEIXOTO, J. R.; JUNQUEIRA, N. T. J.; OLIVEIRA, A. T.; RANGEL, L. E. P. Características físicas e químicas em nove genótipos de maracujá-azedo cultivado sob três níveis de adubação potássica. Revista Brasileira Fruticultura, Jaboticabal, v. 27, n. 1, p. 124-127, 2005. https://doi.org/10.1590/S0100-29452005000100033

GOMES, T. S.; CHIBA, H. T.; SIMIONATO, E. M. R. S.; SAMPAIO, A. C. Qualidade da polpa de maracujá amarelo - seleção Afruvec, em função das condições de armazenamento dos frutos. Alimentos e Nutrição, Araraquara, v. 17, n. 4, p. 401-405, 2006.

GRECO, S. M. L.; PEIXOTO, J. R.; FERREIRA, L. M. Avaliação física, físico-química e estimativas de parâmetros genéticos de 32 genótipos de maracujazeiro azedo cultivados no distrito federal. Bioscience Journal, Uberlândia, v. 30, spp. 1, p. 360-370, 2014.

IAL - Instituto Adolfo Lutz. Métodos químicos e físicos para análise de alimentos. $4^{\mathrm{a}}$ ed. São Paulo: Instituto Adolf Lutz, 2008. 1020p.

IBGE - Instituto Brasileiro de Geografia e Estatística. Produção Agrícola Municipal - Culturas temporárias e permanentes. Rio de Janeiro: IBGE, 2016. 62 p.

JUNQUEIRA, N. T. V.; SANTOS, E. C.; JUNQUEIRA, K. P.; FALEIRO, F. G.; BELLON, G.; BRAGA, M. F. Características físico-químicas e produtividade de acessos de Passiflora nitida Kunth procedentes do CentroNorte do Brasil. Revista Brasileira de Fruticultura, Jaboticabal, v. 32, n. 3, p. 791-797, 2010. https://doi.org/10.1590/S0100-29452010005000102

KISHORE, K.; PATHAK, K. A.; SHUKLA, R.; BHAR, R. Effect of storage temperature on physic-chemical and sensory attributes of purple passion fruit (Passiflora edulis Sims). Journal of Food Science and Technology, Campinas, v. 48, n. 4, p. 484-488, 2011. https://doi.org/10.1007/s13197-010-0189-8 
MACHADO, S. S.; CARDOSO, R. L.; MATSUURA, F. C. A. U.; FOLEGATTI, M. I. S. Caracterização física e físico-química de frutos de maracujá amarelo provenientes da região de Jaguaquara - Bahia. Magistra, Cruz das Almas, v. 15, n. 2, p. 229-233, 2003.

MEDEIROS, S. A. F.; YAMANISHI, O. K; PEIXOTO, J. R; PIRES, M. C; JUNQUEIRA, N. T. V; RIBEIRO, J.G.B.L. Caracterização físico-química de progênies de maracujá-roxo e maracujá-azedo cultivados no Distrito Federal. Revista Brasileira de Fruticultura, Jaboticabal, v. 31, n. 2, p. 492-499, 2009.

https://doi.org/10.1590/S0100-29452009000200025

NEGREIROS, J. R. S.; ARAUJO NETO, S. E.; ÁLVARES, V. S.; LIMA, V. A.; OLIVEIRA, T. K.

Caracterização de frutos de progênies de meios-irmãos de maracujazeiro-amarelo em Rio Branco - Acre.

Revista Brasileira de Fruticultura, Jaboticabal, v. 30, n. 2, p. 431-437, 2008. https://doi.org/10.1590/S010029452008000200028

SALOMÃO, L. C. C. Colheita. In: MATSUURA, F. C. A. U.; FOLEGATTI, M. I. S. (Eds.). Maracujá - Póscolheita. Embrapa Informação Tecnológica, Brasília, 2002. p. 16-18.

SILVA, L. S.; CAVALCANTE, I. H. L.; SOUSA, K. S. M.; GALHARDO, C. X.; SANTANA, E. A.; LIMA, D. D. Qualidade do maracujá amarelo fertirrigado com nitrogênio e substâncias húmicas. Comunicata Scientia, Bom Jesus, v. 6, n. 4, p. 479-487, 2015. https://doi.org/10.14295/cs.v6i4.1701

SOUZA, A. C. G.; SANDI, D. Industrialização. In: BRUCKNER, C.H.; PICANÇO, M.C. (Eds.). Maracujá: tecnologia de produção, pós-colheita, agroindústria, mercado. Porto Alegre: Cinco Continentes, 2001. p. 305-344.

TACO. Tabela brasileira de composição de alimentos. NEPA-UNICAMP. $4^{\mathrm{a}}$ ed. revisada e ampliada. Campinas: NEPA-UNICAMP, 2011. 161p.

TOCCHINI, R. P.; NISIDA, L. A. C.; HASHIZUME, T. III Processamento: produtos, caracterização e utilização. In: ITAL (org). Maracujá - Cultura, matéria prima, processamento e aspectos econômicos. 2 ed. Campinas: ITAL, 1994. p. 161-175. 